Article

\title{
Catalyst Characteristics and Performance of Silica-Supported Zinc for Hydrodeoxygenation of Phenol
}

\author{
Hamed Pourzolfaghar ${ }^{1}{ }^{\circ}$, Faisal Abnisa ${ }^{2}$, Wan Mohd Ashri Wan Daud ${ }^{1, *}$, \\ Mohamed Kheireddine Aroua ${ }^{3,4}$ and Teuku Meurah Indra Mahlia ${ }^{5, *(D)}$ \\ 1 Department of Chemical Engineering, Faculty of Engineering, University of Malaya, \\ Kuala Lumpur 50603, Malaysia; h_pourzolfaghar@yahoo.com \\ 2 Department of Chemical and Materials Engineering, Faculty of Engineering, King Abdulaziz University, \\ Jeddah 21589, Saudi Arabia; fta@kau.edu.sa \\ 3 Centre for Carbon Dioxide Capture and Utilization (CCDCU), School of Science and Technology, \\ Sunway University, Bandar Sunway, Petaling Jaya 47500, Malaysia; kheireddinea@sunway.edu.my \\ 4 Department of Engineering, Lancaster University, Lancaster LA1 4YW, UK \\ 5 School of Information, Systems and Modelling, Faculty of Engineering and Information Technology, \\ University of Technology Sydney, Sydney, NSW 2007, Australia \\ * Correspondence: ashri@um.edu.my (W.M.A.W.D.); TMIndra.Mahlia@uts.edu.au (T.M.I.M.)
}

Received: 25 April 2020; Accepted: 23 May 2020; Published: 1 June 2020

\begin{abstract}
The present investigation aimed to study the physicochemical characteristics of supported catalysts comprising various percentages of zinc dispersed over $\mathrm{SiO}_{2}$. The physiochemical properties of these catalysts were surveyed by $\mathrm{N}_{2}$ physisorption (BET), thermogravimetry analysis (TGA), $\mathrm{H}_{2}$ temperature-programmed reduction, field-emission scanning electron microscopy (FESEM), inductively coupled plasma-optical emission spectrometry (ICP-OES), and $\mathrm{NH}_{3}$ temperature-programmed desorption $\left(\mathrm{NH}_{3}-\mathrm{TPD}\right)$. In addition, to examine the activity and performance of the catalysts for the hydrodeoxygenation (HDO) of the bio-oil oxygenated compounds, the experimental reaction runs, as well as stability and durability tests, were performed using $3 \% \mathrm{Zn} / \mathrm{SiO}_{2}$ as the catalyst. Characterization of silica-supported zinc catalysts revealed an even dispersion of the active site over the support in the various dopings of the zinc. The acidity of the calcinated catalysts elevated clearly up to $0.481 \mathrm{mmol} / \mathrm{g}$. Moreover, characteristic outcomes indicate that elevating the doping of zinc metal led to interaction and substitution of proton sites on the $\mathrm{SiO}_{2}$ surface that finally resulted in an increase in the desorption temperature peak. The experiments were performed at temperature $500{ }^{\circ} \mathrm{C}$, pressure $1 \mathrm{~atm}$; weight hourly space velocity (WHSV) $0.32\left(\mathrm{~h}^{-1}\right.$ ); feed flow rate $0.5(\mathrm{~mL} / \mathrm{min})$; and hydrogen flow rate $150(\mathrm{~mL} / \mathrm{min})$. Based on the results, it was revealed that among all the prepared catalysts, that with $3 \%$ of zinc had the highest conversion efficiency up to $80 \%$. However, the selectivity of the major products, analyzed by gas chromatography flame-ionization detection (GC-FID), was not influenced by the variation in the active site doping.
\end{abstract}

Keywords: heterogeneous catalyst; hydrodeoxygenation (HDO); zinc; phenol; bio-oil

\section{Introduction}

Due to global warming, many countries have moved from fossil fuel-based energy toward renewable energy. There are several forms of renewable energy that have been effectively executed out there. Many countries have successfully implemented renewable energy generated from solar [1,2]. Where some others have successfully utilized hydro, wave, geothermal, and wind as a secondary energy source [1,3], Malaysia and Indonesia have successfully utilized biofuel as one of the alternative 
energy sources [4-6]. Biofuel has been proven to reduce greenhouse gas emissions significantly in these countries [7]. Therefore, among all alternative sources of energy to replace the restricted natural fossil fuel reservoirs, biofuel represents the sole available sustainable energy source that could properly replace petroleum [8,9]. Nevertheless, due to its component's complexity, which results in its instability, corrosiveness, and low heating value, the pyrolyzed biomass, known as bio-oil, must be upgraded before utilization [10-12]. Hydrodeoxygenation is a catalytic reaction that applies hydrogen to eliminate oxygen from the oxygenated compounds. These reactions are an efficient alternative method to attain bio-oils from biomass-derived oxygenated compounds [13]. Nevertheless, several issues must first be addressed before the hydrodeoxygenation (HDO) process can be entirely commercialized. The development of efficient, robust, cost-effective, and selective catalysts enable the advancement of this method to partly prevail these disadvantages [14].

Various kinds of active sites have been tested in the last decade for the HDO of the oxygenated compounds, which have had promising results including transition metal oxides such as $\mathrm{MoO}_{3}[15,16]$, $\mathrm{Mo}_{2} \mathrm{C}$ [17], $\mathrm{Pt} /\left(\mathrm{Al}_{2} \mathrm{O}_{3}, \mathrm{SiO}_{2}, \mathrm{H}-\right.$ Beta zeolie, activated carbon) [18-20], $\mathrm{Fe} /\left(\mathrm{SiO}_{2}\right.$, activated carbon) [21,22], $\mathrm{Ni} /\left(\mathrm{Al}_{2} \mathrm{O}_{3}, \mathrm{SiO}_{2}, \mathrm{HZSM}-5\right.$ zeolite) [23], and $\mathrm{Ga} /\left(\mathrm{HBETA}, \mathrm{SiO}_{2}, \mathrm{ZSM}-5\right)$ [24]; precious metals such as $\mathrm{Ru} / \mathrm{TiO}_{2}$ [25], and W/carbon [26]; phosphides such as $\mathrm{Ni}_{2} \mathrm{P} / \mathrm{SiO}_{2}, \mathrm{Fe}_{2} \mathrm{P} / \mathrm{SiO}_{2}, \mathrm{MoP} / \mathrm{SiO}_{2}, \mathrm{Co}_{2} \mathrm{P} / \mathrm{SiO}_{2}$, and $\mathrm{WP} / \mathrm{SiO}_{2}$ [27]; and bifunctional such as $\mathrm{NiMo} / \mathrm{Al}_{2} \mathrm{O}_{3}$ [28] and $\mathrm{Pd}-\mathrm{FeOX} / \mathrm{SiO}_{2}$ [29].

Zinc has been reported as an active site for the hydroprocessing of bio-oil oxygenated compounds, resulting in aromatic compounds and/or hydrocarbons [30-38]. The interdependent effect of nickel and zinc metals on $\mathrm{Al}_{2} \mathrm{O}_{3}$ support has been investigated by Cheng et al. [39]. They found that the pine sawdust bio-oil could efficiently be converted by $15 \% \mathrm{Ni} .5 \% \mathrm{Zn} / \mathrm{Al}_{2} \mathrm{O}_{3}$ at $44.64 \mathrm{wt} \%$. According to their report, the highest hydrocarbon content of $50.12 \%$ could be achieved by applying this bifunctional catalyst. Bifunctional catalysts possess two types of active sites and catalyze two dissimilar types of reactions. In another study by Parsell et al. [40], Zn/Pd was used for the HDO of lignin. Based on the author's claims, $80 \%-90 \%$ of conversion yield could be achieved using $\mathrm{Pd} / \mathrm{Zn}$ as the HDO catalyst. Besides, they reported that the bifunctional $\mathrm{Pd} / \mathrm{Zn} / \mathrm{C}$ catalyst was more effective in the HDO of lignin molecules ( $\beta-\mathrm{O}-4)$ and aromatic compounds, in comparison to the $\mathrm{Pd} / \mathrm{C}$ sample. Additionally, they expressed that the bifunctional $\mathrm{Pd} / \mathrm{Zn} / \mathrm{C}$ sample is recyclable and robust, and no further addition of the zinc metal is required after each reaction cycle. The efficiency upsurge of the Kapuk seed oil hydrocracking process using the zinc metal has been reported recently by Mirzayanti et al. [41]. They stated that using Zn-Mo/HZSM-5 with a loading of $2.99 \mathrm{wt} \%$ for $\mathrm{Zn}$ and $7.55 \mathrm{wt} \%$ for Mo, the highest performance of the catalyst for the hydrocracking process could be reached.

Due to the complexity of the bio-oils causing complicated reactions during the HDO process, model compounds such as phenol, lignin, and others have been applied. Using the model compounds, one can attain enough data regarding the mechanism and reaction networks of the process. Phenol and its derivatives are known as the most refractory compound in the bio-oil and, hence, it has been selected as the model compound in this investigation [42].

The current research aims to study the physicochemical characteristics of the $\mathrm{Zn} / \mathrm{SiO}_{2}$ catalyst as a potential and promising catalyst for the HDO of bio-oil oxygenated compounds using various analytical equipment. Furthermore, using the phenol as a model compound for the oxygenated bio-oil compound, the reactivity, performance, stability, and reusability of the selected catalyst have been examined in a continuous fixed-bed reactor.

\section{Materials and Methods}

\subsection{Materials}

Zinc powder (used to synthesize $\mathrm{Zn} / \mathrm{SiO}_{2}$ ), anhydrous benzene (99.8\%), phenol ( $\geq 89 \%$ ), HPLC grade cyclohexane $(99.9 \%)$, acetone (HPLC grade), and analytical tetrahydrobenzene or cyclohexene $(99 \%)$ were purchased from Sigma Aldrich (St. Louis, MO, USA). Synthesis grade n-decane $(\geq 95 \%)$ and $\mathrm{SiO}_{2}$ (Pure silica) have been purchased from Aldrich and $\mathrm{R} \& \mathrm{M}$ chemicals, respectively. 


\subsection{Catalyst Synthesis}

The incipient wetness impregnation method was used in this investigation to prepare the catalyst samples with various doping percentages of the zinc metal onto the silica surface. Silica-supported $3 \%$ zinc was prepared using $10 \mathrm{~g}$ of silica (catalyst support) and $0.31 \mathrm{~g}$ of the powdered $\mathrm{Zn}$ metal and some water. The compounds were mixed in a stirrer, roughly $2 \mathrm{~h}$. Afterward, it was dried overnight in an electric oven at $105^{\circ} \mathrm{C}$. The dried sample was then taken to a furnace for the calcination step for $5 \mathrm{~h}$ under $500^{\circ} \mathrm{C}$ and air atmosphere. Other impregnated samples were prepared with the same procedure.

\subsection{Characterization of the Catalysts}

The prepared calcinated catalysts and the bare support were analyzed by XRD (PANalytical $\mathrm{X}^{\prime}$ Pert with $\mathrm{Cu}-\mathrm{K} \alpha$ radiation). Scherrer's formula was applied to estimate the crystallite size of silica-supported zinc catalysts. In Equation (1), $\lambda$ represents the X-ray wavelength, $d_{x r d}$ denotes the mean size of the crystallite, $\beta_{h k l}$ stands for the full-width at half-maximum (FWHM), $k$ is the shape factor, and $\theta$ denotes the Bragg angle. Data were collected at ambient conditions at a scanning range from $5^{\circ}$ to $80^{\circ}$ with a step size of $0.0260^{\circ}$. The slit and the time step were set to $0.1 \mathrm{~mm}$ and $0.1 \mathrm{~s}$, respectively.

$$
d_{x r d}=\frac{k \lambda}{\beta_{h k l} \cos \theta}
$$

$\mathrm{N}_{2}$-adsorption analysis was performed using a Micromeritics TrisStar II 3020 V1.04 to detect the BET surface area, pore size, and pore volume of the calcinated catalysts in this study. The measurement temperature was set at $-196{ }^{\circ} \mathrm{C}$ and the degassing of the catalysts were performed for one hour at $90^{\circ} \mathrm{C}$ and, subsequently, $4 \mathrm{~h}$ at $200{ }^{\circ} \mathrm{C}$, prior to the test and under vacuum atmosphere.

Thermogravimetric (TGA) analysis was employed for the bare $\mathrm{SiO}_{2}$ and freshly calcinated catalysts to examine the extent of water and organic compounds on the samples. A TGA Q500 V20.10 (TA instruments) instrument was applied in this survey. In a typical run, $80 \mathrm{mg}$ of a sample was placed in the sample holder and was heated with a heating rate of $20^{\circ} \mathrm{C} / \mathrm{min}$ up to $800{ }^{\circ} \mathrm{C}$.

$\mathrm{H}_{2}$ temperature-programmed reduction $\left(\mathrm{H}_{2}\right.$-TPR) was conducted by a Micromeritics Chemisorb 2720 apparatus. Prior to hydrogen adsorption, using the pure nitrogen at $500{ }^{\circ} \mathrm{C}$, the samples were outgassed for $30 \mathrm{~min}$. Subsequently, the catalysts were reduced, using $5 \%$ hydrogen diluted in argon gas, for one hour and $500{ }^{\circ} \mathrm{C}$. In the following, the catalysts were cooled and, to remove the physically adsorbed molecules, flushed with $\mathrm{N}_{2}$ gas at a flow rate of $20 \mathrm{~mL} / \mathrm{min}$. Finally, the catalysts were heated up to $900{ }^{\circ} \mathrm{C}$ in the nitrogen atmosphere. A thermal conductivity detector (TCD) monitored and recorded the $\mathrm{H}_{2}$ consumption during the reduction process.

A QUANTA 450 FEG instrument was applied for the FESEM analysis. The morphology of two calcinated catalysts $\left(1 \% \mathrm{Zn} / \mathrm{SiO}_{2}\right.$ and $\left.3 \% \mathrm{Zn} / \mathrm{SiO}_{2}\right)$ and the bare silica was examined.

Inductively coupled plasma optical emission spectrometry (ICP-OES) was applied to determine the metal content of the prepared catalysts. In this analysis, $100 \mathrm{mg}$ of each catalyst was digested with $\mathrm{HNO}_{3}(10 \mathrm{~mL})$. Zinc metal solutions for the calibration standard preparation were made using a certain quantity of $\mathrm{Zn}$ metal to $7 \mathrm{~mL}$ of nitric acid and $14 \mathrm{~mL}$ of distilled water, for each standard sample.

The total acidity of the prepared catalysts was tested using the $\mathrm{NH}_{3}$-TPD method. Prior to outgassing the catalyst $(50 \mathrm{mg})$ in the quartz U-tube, it was heated from room temperature up to $300{ }^{\circ} \mathrm{C}$. Then, under a flow rate of $20 \mathrm{~mL} / \mathrm{min}$ of helium, the sample was degassed for $30 \mathrm{~min}$ at $300{ }^{\circ} \mathrm{C}$. Subsequently, the catalyst was cooled down to room temperature and was then ready for the ammonia chemisorption step. A $5 \% \mathrm{NH}_{3} / \mathrm{He}$ gas mixture was selected for this step and the ammonia chemisorbed on the sample for $30 \mathrm{~min}$. To remove the physisorbed molecules, the sample was purged using the helium gas at $100{ }^{\circ} \mathrm{C}(30 \mathrm{~min})$. Finally, applying the heating rate of $40{ }^{\circ} \mathrm{C} / \mathrm{min}$, the sample was heated up to $900^{\circ} \mathrm{C}$ in the helium atmosphere $(20 \mathrm{~mL} / \mathrm{min})$. For this analysis, a Micromeritics apparatus was used (Model: Chemisorb 2720). 


\subsection{Reactivity Studies}

The reactivity and selectivity analysis of the prepared catalysts was performed by passing the phenol gas through the catalyst in a stainless-steel fixed-bed reactor. An accurate reaction temperature was observed using an external thermocouple (Type K) located inside the reactor and next to the sample. In a typical run, $1 \mathrm{~g}$ of the sample was placed in the middle of the reactor. Prior to the main experiments at $500{ }^{\circ} \mathrm{C}$, the samples were purged for one hour using the nitrogen gas with a $150 \mathrm{~mL} / \mathrm{min}$ flow rate. Subsequently, the catalyst was activated for $2 \mathrm{~h}$ by hydrogen gas at $500{ }^{\circ} \mathrm{C}$ and $100 \mathrm{~mL} / \mathrm{min}$ of flow rate. The main experiment began by injecting the feed to the reactor using an HPLC pump (Model: PU-980, JASCO) under $\mathrm{N}_{2}$ gas atmosphere. For analysis of the reaction products, the gas-phase products were collected using a condenser connected to a chiller. To obtain the run time of each product including cyclohexane, cyclohexene, and benzene, as well as n-hexane, phenol, and acetone, the standard curves have been created using the standard solutions.

\subsection{Catalyst Stability and Reusability Study}

To perform the stability test of the prepared catalysts in this study, a freshly prepared $3 \% \mathrm{Zn} / \mathrm{SiO}_{2}$ catalyst was selected. The collected data from the HDO reaction at various times on stream (TOSs) were used for calculating the conversion efficiency of the phenol. The obtained results will reveal the variation in activity and selectivity of the catalyst applied with TOS. A reusability study was done in the fixed-bed reactor and the sample applied for the stability test was regenerated at $500{ }^{\circ} \mathrm{C}$ under the air atmosphere (for $1 \mathrm{~h}$ in an electrical furnace). The liquid products were collected and further analyzed using GC-FID analysis.

\section{Results}

\subsection{Characterization of the Catalyst}

\subsubsection{XRD}

Figure 1 represents the XRD diffractograms of the silica-supported zinc catalysts at various loadings and the bare $\mathrm{SiO}_{2}$. The XRD patterns of the samples confirmed the existence of $\mathrm{Zn}$ metal in all zinc-doped catalysts (b, c, d, and e). According to the literature, the observed peaks at certain $2 \theta$ values $\left(32^{\circ}, 34^{\circ}, 36^{\circ}, 47^{\circ}, 56^{\circ}, 63^{\circ}\right.$, and $\left.68^{\circ}\right)$ represent hexagonal zinc [43]. Table 1 shows the calculated average size of zinc (calculated from $2 \theta=32^{\circ}, 34^{\circ}$, and $36^{\circ}$ ) crystallite, which was elevated with the increment in $\mathrm{Zn}$ metal doping. This phenomenon occurs due to the agglomeration of the zinc particles outside the pores [44]. The diffraction peaks of some planes including (112), (200), and (110) have not been found, due to the good dispersion of the small crystallites formed during the impregnation or forming in negligible quantity. Comparable degrees of crystallinity and slight peak broadening of all XRD diffractograms indicate that the addition of 0.5-3 wt $\% \mathrm{Zn}$ metal insignificantly transformed the crystallinity of the samples. The peaks of $\mathrm{Zn}$ metal crystallites (Figure 1) were not distinguished, probably due to the decent diffusion of $\mathrm{Zn}$ particles in the surface of the support $\left(\mathrm{SiO}_{2}\right)$ or the low quantity of the zinc.

Table 1. Physicochemical characteristics results of the bare $\mathrm{SiO}_{2}$ and $\mathrm{Zn}$-doped catalysts.

\begin{tabular}{|c|c|c|c|c|c|c|}
\hline $\begin{array}{c}\text { Catalyst } \\
\text { (Nominal Loading) }\end{array}$ & $\begin{array}{l}\mathrm{S}_{\text {BET }} \\
\left(\mathrm{m}^{2} / \mathrm{g}\right)\end{array}$ & $\begin{array}{l}\mathrm{d}_{\mathrm{XRD}} \\
(\mathrm{nm})\end{array}$ & $\begin{array}{l}\text { Pore Volume } \\
\quad\left(\mathrm{cm}^{3} / \mathrm{g}\right)\end{array}$ & $\begin{array}{l}\text { Pore Size } \\
\text { (§) }\end{array}$ & $\begin{array}{c}\text { Real Doped Zn } \\
(w t \%)\end{array}$ & $\begin{array}{l}\text { Acidity of Catalyst } \\
(\mathrm{mmol} / \mathrm{g})\end{array}$ \\
\hline Bare $\mathrm{SiO}_{2}$ & 185.5 & - & 1.300 & 280.220 & - & 0.108 \\
\hline $0.5 \% \mathrm{Zn} / \mathrm{SiO}_{2}$ & 185.2 & 48 & 1.300 & 280.220 & 0.46 & 0.357 \\
\hline $1 \% \mathrm{Zn} / \mathrm{SiO}_{2}$ & 184.7 & 49 & 1.300 & 280.940 & 0.91 & 0.370 \\
\hline $2 \% \mathrm{Zn} / \mathrm{SiO}_{2}$ & 181 & 51 & 1.274 & 281.906 & 1.8 & 0.422 \\
\hline $3 \% \mathrm{Zn} / \mathrm{SiO}_{2}$ & 173.3 & 60 & 1.284 & 283.819 & 2.53 & 0.481 \\
\hline
\end{tabular}




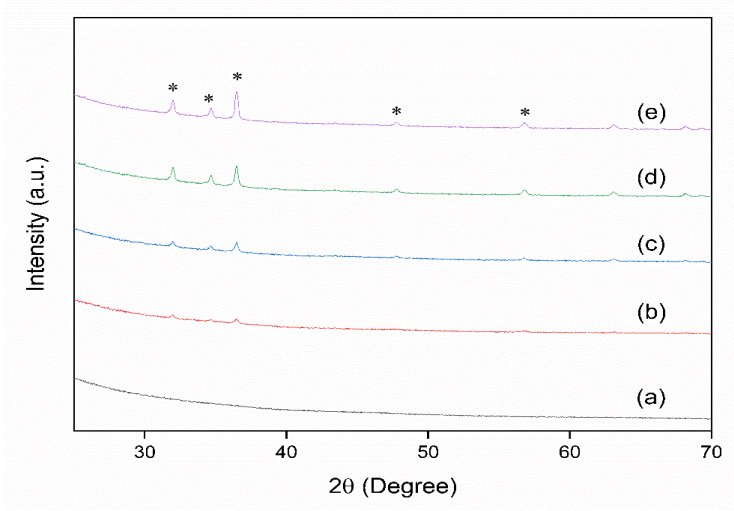

Figure 1. XRD patterns of bare $\mathrm{SiO}_{2}$ and doped catalysts applied in this study [bare $\mathrm{SiO}_{2}$ (a), $0.5 \% \mathrm{Zn} / \mathrm{SiO}_{2}$ (b), $1 \% \mathrm{Zn} / \mathrm{SiO}_{2}$ (c), $2 \% \mathrm{Zn} / \mathrm{SiO}_{2}$ (d), and $3 \% \mathrm{Zn} / \mathrm{SiO}_{2}$ (e)].

\subsubsection{BET}

The surface area, pore size, and pore volume of the bare silica and the freshly calcinated sample values have been detailed in Table 1 . The analysis results specified that the BET surface area of the calcinated impregnated samples was slightly lower than the bare $\mathrm{SiO}_{2}$. Nie [45] has also reported the same range of surface area for the silica. The surface area and pore volume of the impregnated samples, as expected and documented previously in the literature, decreased by increasing the zinc load on the support surface $[46,47]$. In a study by Clerk et al., they declared that various loadings of molybdenum and the surface result in a decrease in the BET surface area [48]. Whilst the loading of the active site resulted in an increase in the BET surface area and pore volume of the samples, it caused decreases in the pore sizes of the samples. This expected trend is due to the selective closing of the small pores with the loading of the zinc metal of the surface of the $\mathrm{SiO}_{2}$ [49]. According to the results, all samples offered type IV isotherms, which indicate a mesoporous texture with capillary condensation.

\subsubsection{Thermogravimetric Analysis (TGA)}

Thermogravimetry analysis was performed to detect the content of the water and organic compounds of all calcinated samples, and their weight loss was recorded as a function of temperature. TGA results of the samples are presented in Figure 2. In all cases, the weight loss occurred up to $100{ }^{\circ} \mathrm{C}$, which is mainly due to the humidity. As it can be observed from Figure 2, calcinated bare $\mathrm{SiO}_{2}$ has around a $2 \%$ weight loss whilst the calcinated metalized samples have a minor one (less than $1 \%$ ). This specifies that by loading the support by zinc metal, less humidity can be absorbed, thus having lower weight loss during the HDO experiments. No high-temperature weight loss was monitored in TGA analysis, which indicates that the samples had no organic carbon impurites.

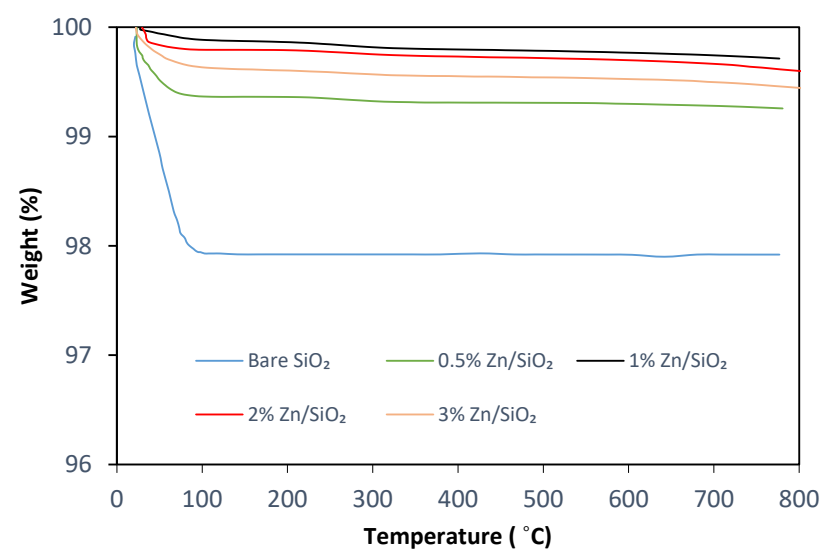

Figure 2. Thermogravimetric analysis for the samples as a function of temperature. 


\subsection{4. $\mathrm{H}_{2}$-TPR}

Figure 3 represents the results for the reducibility of the bare silica and the calcinated samples, which were investigated by $\mathrm{H}_{2}$-TPR. Some preliminary tests of the $\mathrm{SiO}_{2}$ support showed that it did not consume any hydrogen (between $300{ }^{\circ} \mathrm{C}$ to $700{ }^{\circ} \mathrm{C}$ ). Accordingly, any usage of hydrogen gas in the impregnated catalysts could be credited to the $\mathrm{Zn}$ metal doped on the silica support. The catalyst with $0.5 \% \mathrm{Zn}$ loading showed the lowest maximum reduction temperature $\left(T_{\max }\right)$ at $448^{\circ} \mathrm{C}$. The $T_{\max }$ of the impregnated samples gradually raised with the elevation in $\mathrm{Zn}$ doping probably due to the elevation in the crystallite size of the active metal on the surface of the support. This outcome agrees with the abovementioned XRD findings. Therefore, the $3 \% \mathrm{Zn} / \mathrm{SiO}_{2}$ sample offered the uppermost maximum reduction in temperature among other catalysts $\left(498^{\circ} \mathrm{C}\right)$.

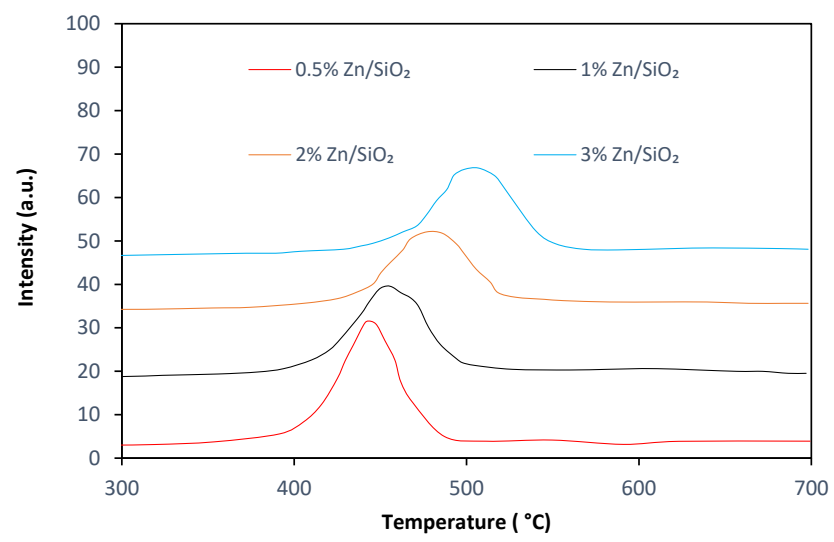

Figure 3. Temperature-programmed reduction profiles of the impregnated catalysts.

\subsubsection{FESEM}

Micrographs of the bare silica and the selected impregnated catalysts are presented in Figure 4 $\left(1 \% \mathrm{Zn} / \mathrm{SiO}_{2}\right.$ and $\left.3 \% \mathrm{Zn} / \mathrm{SiO}_{2}\right)$. The image of the silica represents a big slab formed surface with clusters of silica nanoparticles. From the micrographs of the impregnated samples, it can be perceived that the bright spots, which are the zinc metal, become more densely colonized as the $\mathrm{Zn}$ loading was elevated from $1 \%$ to $3 \%$. However, no agglomeration of the zinc metal particles has been detected in the sample with the highest loading of the active site $\left(3 \% \mathrm{Zn} / \mathrm{SiO}_{2}\right)$. Previous studies have mentioned that by overloading the catalyst surface by an active site, some of the particles might cause agglomeration and might, therefore, result in a reduction in the catalyst performances [44].

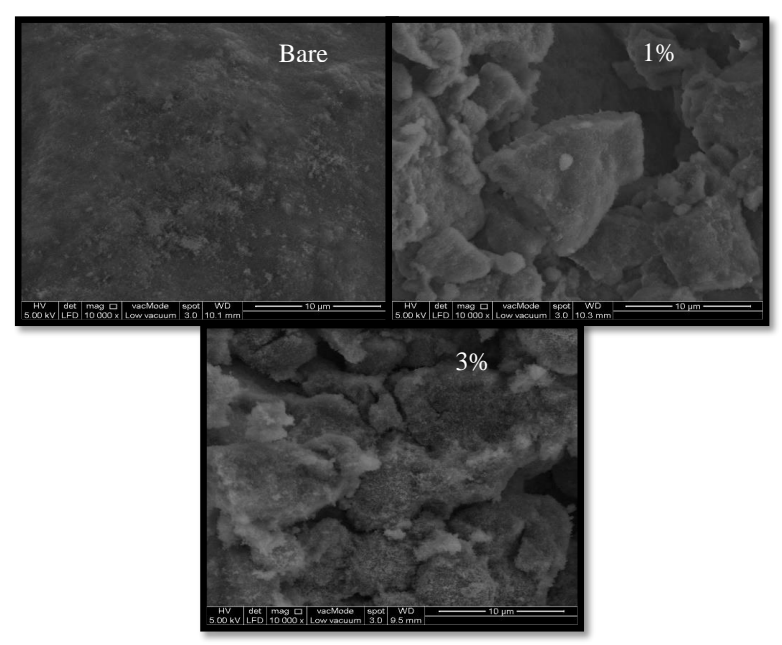

Figure 4. Field-emission scanning electron microscopy (FESEM) micrographs of the selected samples. 


\subsubsection{ICP-OES}

The metal content of each catalyst was detected using ICP-OES analysis (Perkin Elmer, Optima 5300DV). Table 1 indicates the analysis result for the catalysts. In all samples, as shown in the Table, the real metal contents were slightly lower than the calculated extent. The variant between the calculated and real extent of zinc metal on the silica support was between $8 \%-15 \%$. The calculated variant was mainly because of the impurity of the $\mathrm{Zn}$ as the error percentages elevated with the increase in the doped percentages of the impregnated catalysts.

\subsection{7. $\mathrm{NH}_{3}-\mathrm{TPD}$}

Figure 5 represents the NH3-TPD profile of the catalysts. It can be observed that all samples absorb ammonia in a broad range of temperatures $\left(100{ }^{\circ} \mathrm{C}-800{ }^{\circ} \mathrm{C}\right)$. From Figure 5 and Table 1 , it can be observed that after the $0.5 \%-3 \%$ zinc metal was doped on $\mathrm{SiO}_{2}$, the total acidity of the impregnated samples evidently raised and an elevation in the area of the ammonia desorption peak could be perceived. Furthermore, considering the desorption peak temperature of the samples, the position of the $\mathrm{NH}_{3}$ desorption peak temperatures increased by elevating the zinc doping to the samples. It could be concluded that doping the zinc metal onto the silica surface results in the interaction and exchange of proton sites on the support surface. This might be due to the interaction and exchange of proton spots on the silica surface with the loading of zinc metal, initiating the renewal of new proton spots on the samples. As Table 1 indicates, the total acidity of the catalysts was expressively raised from 0.108 to $0.481 \mathrm{mmol} / \mathrm{g}$ within the upsurge in zinc doping from $0 \%$ to $3 \%$. According to Kernajanakon et al. [50], loading the optimum amount of active sites on the support is crucial and ranges from $1 \%$ to $2.5 \%$. By increasing the loading amount such as $5 \%$ and $10 \%$, the acidity of the catalysts decreases due to the concealing of acid spots by the produced $\mathrm{ZnO}$ cluster. Furthermore, the authors implied that the dispersion efficiency of the metal on the surface of the support might be influenced by the amount of the loaded metal.

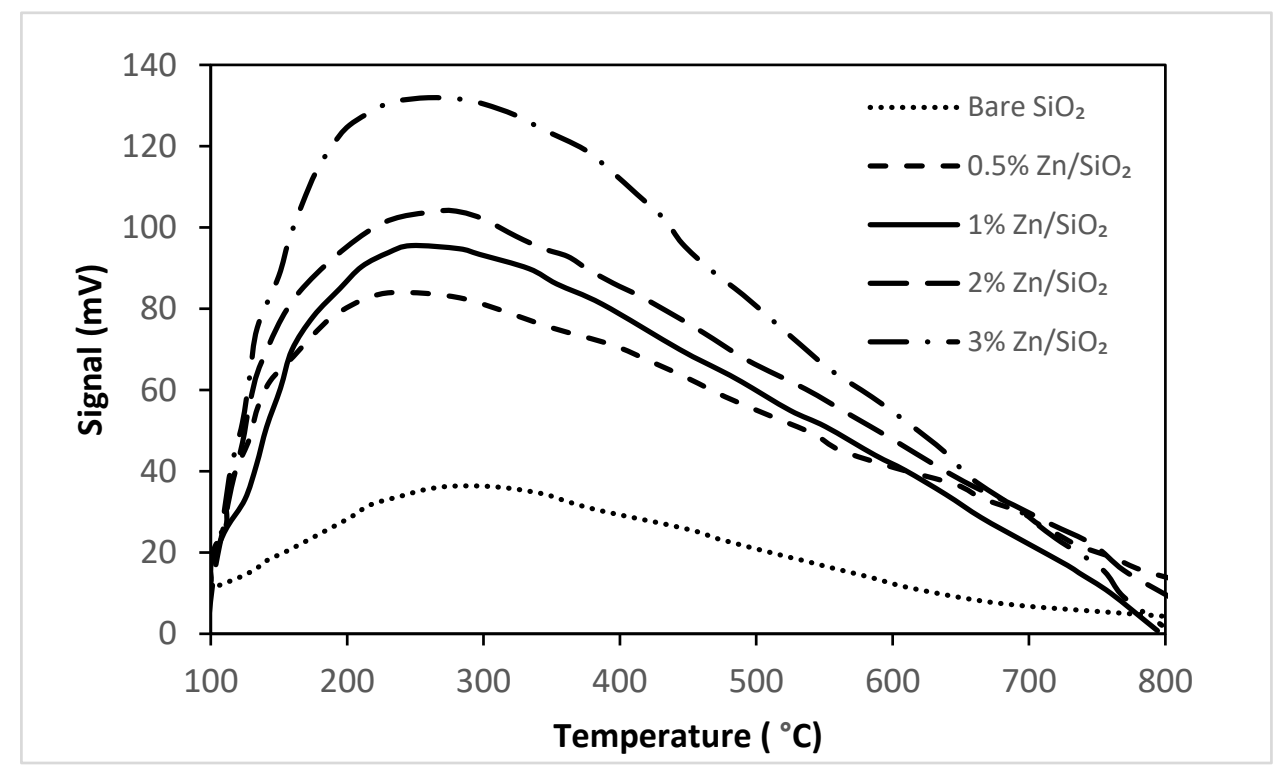

Figure 5. $\mathrm{NH}_{3}-\mathrm{TPD}$ profile of the impregnated catalysts and the bare $\mathrm{SiO}_{2}$.

\subsection{Reactivity}

Products selectivity and phenol conversion over $x \mathrm{Zn} / \mathrm{SiO}_{2}$ catalysts in the hydrodeoxygenation of phenol at various loadings of the zinc metal are shown in Figure 6. From Figure 6, it can be perceived that all impregnated samples are active and able to convert the phenol. Table 2 details the data attained by GC-FID analysis. Phenol conversion efficiency using various loads of Zn metal, 0.5-3\%, varied 
from $15 \%$ to $80 \%$, respectively. By elevating the zinc metal loading of the catalysts, the total conversion increased, and the highest conversion efficiency was achieved with $3 \%$ doping of the active site. In a separate study [42], we observed that a loading of $4 \%$ of the active metal $(\mathrm{Zn})$ on the support surface $\left(\mathrm{SiO}_{2}\right)$ resulted in a slight reduction in the HDO conversion efficiency. The main reason was found to be the occupation of the support surface pores by zinc metal. However, the zinc metal loading $(0.5-3 \%)$ had a slight effect (up to $13 \%$ ) on the selectivity of the products including cyclohexane, cyclohexene, and phenol. The selectivity of the cyclohexane represents the highest value $(71.62 \%)$ using the $2 \%$ $\mathrm{Zn} / \mathrm{SiO}_{2}$. However, around a $3.14 \%$ decrease has been observed in its selectivity, by elevating the loading of the active site from $2 \%$ to $3 \%$. This minor reduction in selectivity might be referred to the occupying of the surface porosities by the zinc metal nanoparticles.

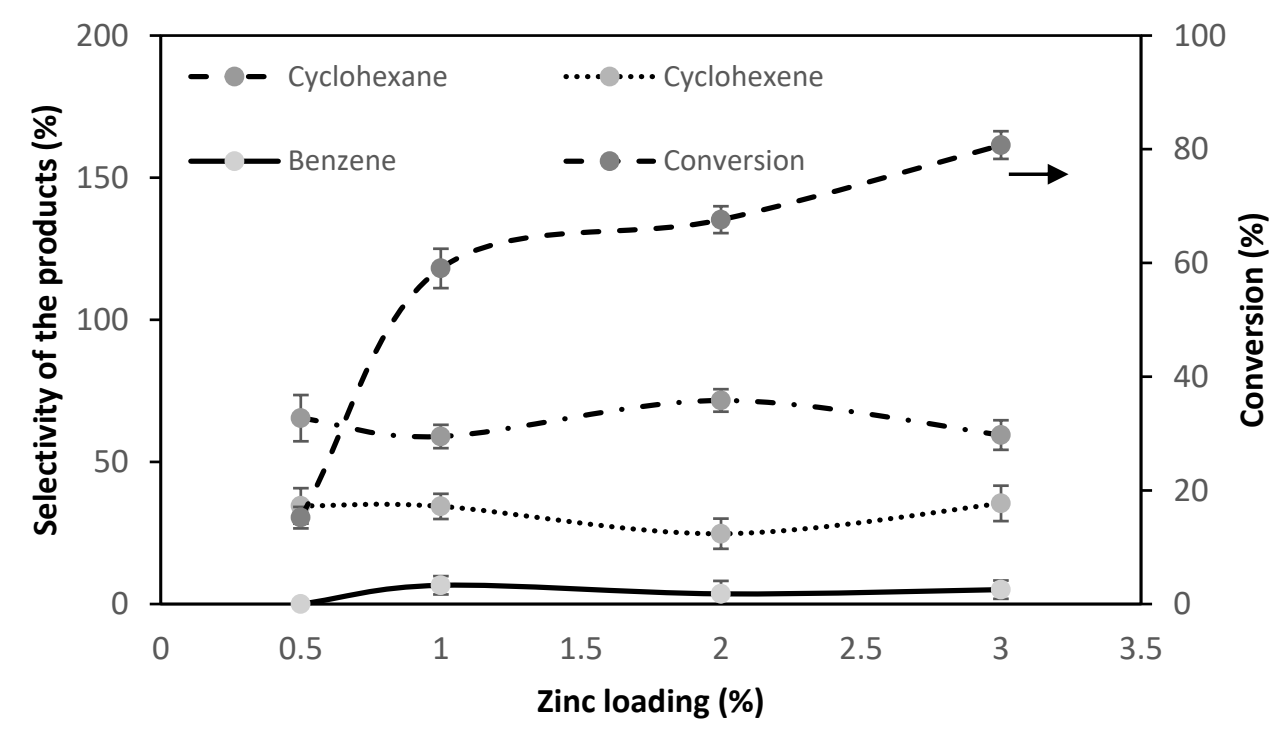

Figure 6. Conversion efficiency and selectivity of the products at various dopings of $\mathrm{Zn}$ metal.

Table 2. Results of selectivity and performance of the catalysts.

\begin{tabular}{ccccc}
\hline \multirow{2}{*}{$\begin{array}{c}\text { Catalyst } \\
\text { (Nominal Loading) }\end{array}$} & $\begin{array}{c}\text { Conversion of } \\
\text { Phenol (\%) }\end{array}$ & Benzene & Cyclohexene & Cyclohexane \\
\cline { 3 - 5 } & 15 & 0 & 34.57 & 65.43 \\
$0.5 \% \mathrm{Zn} / \mathrm{SiO}_{2}$ & 59 & 6.62 & 34.40 & 58.98 \\
$1 \% \mathrm{Zn} / \mathrm{SiO}_{2}$ & 68 & 3.60 & 24.78 & 71.62 \\
$2 \% \mathrm{Zn} / \mathrm{SiO}_{2}$ & 80 & 6.10 & 25.42 & 68.48 \\
$3 \% \mathrm{Zn} / \mathrm{SiO}_{2}$ & & & \\
\hline
\end{tabular}

Note: The experimental conditions for all samples include temperature $500^{\circ} \mathrm{C}$; pressure $1 \mathrm{~atm} ; \mathrm{WHSV}\left(\mathrm{h}^{-1}\right) 0.32$; feed flow rate $(\mathrm{mL} / \mathrm{min}) 0.5$; and hydrogen flow rate $(\mathrm{mL} / \mathrm{min}) 150$.

\subsection{Catalyst Stability and Reusability}

The catalyst with the highest reactivity, $3 \% \mathrm{Zn} / \mathrm{SiO}_{2}$, was selected for the stability studies of phenol HDO. To identify the activity alteration of the catalyst with the time on stream, the conversion of the phenol was assessed using the extracted experimental data at various TOS (Figure 7). As can be illustrated from the Figure, the catalyst was highly active up to $240 \mathrm{~min}$ with a minor decrease in inactivity. Following that, the activity of the catalyst steadily diminished with elevating TOS. After around $340 \mathrm{~min}$ of TOS, the alteration in the catalyst activity became insignificant and was around $43 \%$. Additionally, the variation in the product selectivity was likewise insignificant after $420 \mathrm{~min}$ of the TOS. In terms of the selectivity of the products, after a TOS of $420 \mathrm{~min}$, the selectivity of the cyclohexane slightly decreased with a minor increase in the selectivity on cyclohexene. Henceforth, from the stability results, it could be concluded that the silica-supported zinc with $3 \%$ loading is highly active until $340 \mathrm{~min}$ and, after that, must be replaced or regenerated. 


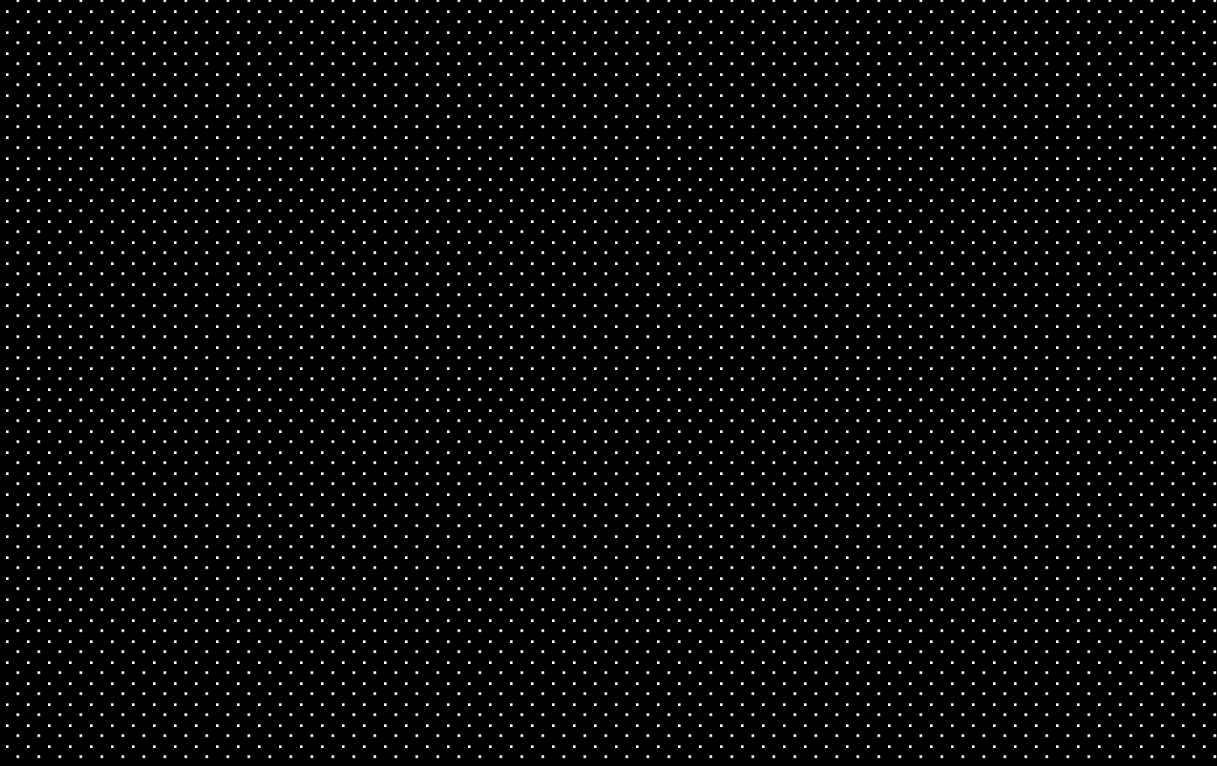

Figure 7. Alteration of the products selectivity and conversion efficiency of phenol with time on stream (TOS). Catalyst $3 \% \mathrm{Zn} / \mathrm{SiO}_{2}$; temperature $500{ }^{\circ} \mathrm{C}$; pressure $1 \mathrm{~atm}$; weight hourly space velocity (WHSV) $\left(\mathrm{h}^{-1}\right)$ 0.32; feed flow rate $(\mathrm{mL} / \mathrm{min}) 0.5$; and hydrogen flow rate $(\mathrm{mL} / \mathrm{min}) 150$.

The applied catalyst for the stability test has been used for the reusability study. The spent catalyst was regenerated by calcination at $500{ }^{\circ} \mathrm{C}$ for one hour under the air atmosphere after each cycle. The freshly calcinated sample was then examined by the HDO of phenol. This procedure was continued until four cycles of regeneration. Figure 8 represents the results of the regeneration study. As can be perceived from the Figure, the catalyst recovered fully and had almost the same results as the fresh catalyst in its first and second regeneration steps. In the third and fourth cycles of regeneration, the conversion efficiency of the catalyst was eliminated. The main reason for eliminating the phenol conversion efficiency after the third regeneration cycle might be because of coking and occupying the pores of the support.

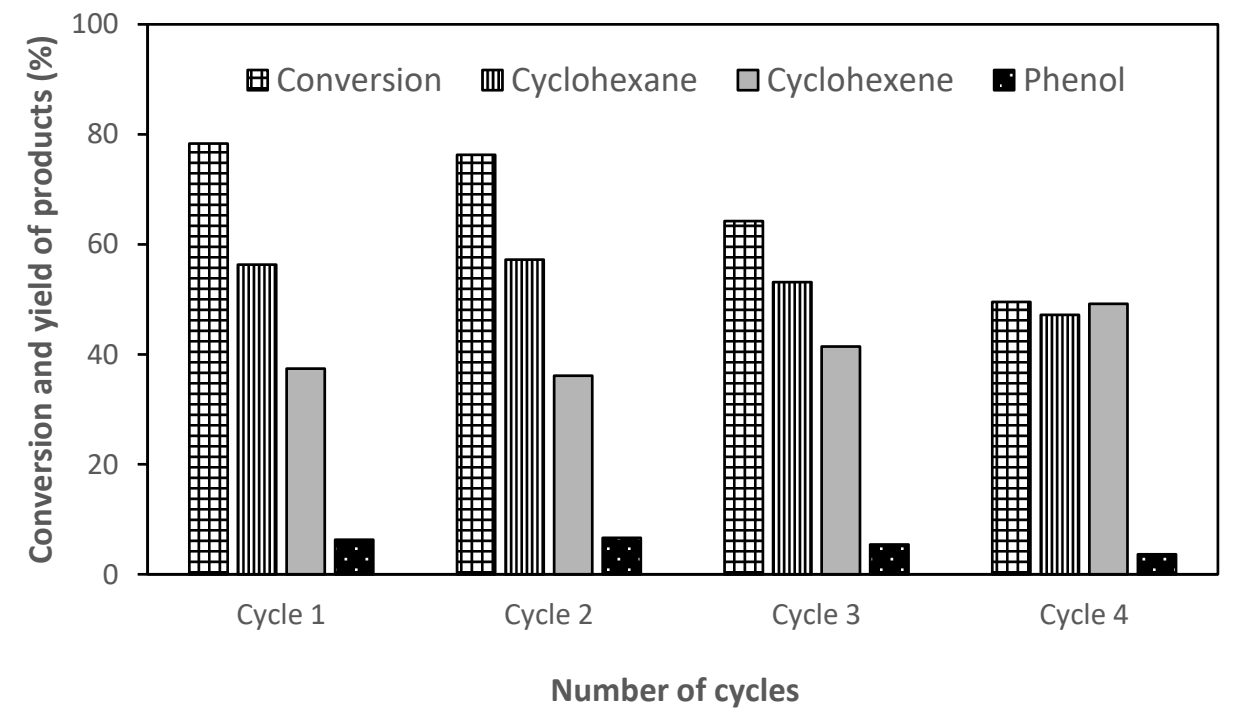

Figure 8. Catalyst reusability survey displaying the conversion and yield of products for hydrodeoxygenation of phenol over $3 \% \mathrm{Zn} / \mathrm{SiO}_{2}$. Temperature $500{ }^{\circ} \mathrm{C}$; pressure $1 \mathrm{~atm}$; WHSV $\left(\mathrm{h}^{-1}\right.$ ) 0.32; feed flow rate $(\mathrm{mL} / \mathrm{min}) 0.5$; and $\mathrm{H}_{2}$ volumetric flow rate $(\mathrm{mL} / \mathrm{min}) 150$. 


\section{Discussions}

A catalyst characterization study using various analytical techniques including XRD, BET, TGA, $\mathrm{H}_{2}$-TPR, $\mathrm{NH}_{3}$-TPD, and ICP-OES along with topography analysis of the samples using the FESEM method revealed that the zinc metal is a promising active site to be applied for hydrodeoxygenation of oxygenated compounds such as phenol. Zinc is an abundant element in the earth's crust, which makes it a promising candidate as a cost-effective active site. Thermogravimetry analysis revealed that the silica-supported zinc catalysts are highly stable at high temperatures up to $800^{\circ} \mathrm{C}$, which is a crucial factor for a catalyst to be applied for HDO reactions. High surface area and large porosities of the samples, analyzed by $\mathrm{N}_{2}$-adsorption analysis, make the surface reactions possible during the HDO process. Significant $\mathrm{H}_{2}$ consumption of the samples in the range of $400-550{ }^{\circ} \mathrm{C}$ explored by $\mathrm{H}_{2}-\mathrm{TPR}$ proved that the catalysts have decent reducibility due to the zinc metal. Furthermore, as it can be perceived from Figure 3, all the samples have one broad peak, which is representative of the one-step reduction of the active metal. Based on the literature [50], the surface acidity of a catalyst plays an important role in the reactivity and selectivity of the HDO reactions. In other words, higher acidity results in a higher conversion efficiency and selectivity of the products. $\mathrm{NH}_{3}$-TPD analysis proved that the total acidities of the samples were in the range of $0.108-0.481 \mathrm{mmol} / \mathrm{g}$. Elevating the active site doping resulted in a higher value for the total acidity, and the sample with $3 \%$ of $\mathrm{Zn}$ represented the highest surface acidity of $0.408 \mathrm{mmol} / \mathrm{g}$. The topography analysis micrographs (Figure 4 ) of the selected samples showed no sign of agglomeration of the zinc metals on the silica surface. Agglomeration is an imperative reason for a reduction in conversion efficiency [51].

Along with the characterization analysis, reactivity analysis revealed that the highest conversion efficiency could be achieved using the sample with $3 \%$ metal loading $(80 \%)$, which was predictable. The selectivity of the HDO reaction products was analyzed using the GC-FID method and revealed that the products of the reactions were cyclohexane, cyclohexene, and benzene. According to the literature [52-54], hydrodeoxygenation of phenol progresses through two dissimilar reaction mechanisms. The first one is breaking the $\mathrm{C}-\mathrm{O}$ bonds of phenol through direct hydrogenolysis. The final main product of this mechanism is cyclohexane. The second mechanism proceeds through hydrogenation of the aromatic ring, which results in different products in comparison to the first mechanism such as cyclohexanone, cyclohexanol, cyclohexene, and cyclohexane. Accordingly, regarding the selectivity of the products, the second mechanism is the main route in this survey.

\section{Conclusions}

In summary, the catalyst characterization study revealed that the physicochemical properties of zinc-supported catalysts depended on their active site content. The incorporation of zinc as an active site over $\mathrm{SiO}_{2}$ mostly involved the filling of pores with zinc, which occupied up to $6.58 \%$ of the surface area. The accumulation of zinc on silica also caused an upsurge in acid site concentration due to the regeneration of new proton sites on the catalyst. The effect of metal loading amount on the catalyst performance was also studied in a continuous fixed-bed reactor. It was found that $3 \% \mathrm{Zn} / \mathrm{SiO}_{2}$ represents the highest phenol conversion efficiency among other samples. However, the results indicate that the selectivity of the products including cyclohexane, cyclohexene, and phenol remained almost steady by varying the doping amount of the active site. The time-on-stream investigation showed that the silica-supported zinc was highly active up to $240 \mathrm{~min}$ of phenol HDO, with a conversion efficiency up to $80 \%$, and after $420 \mathrm{~min}$ of TOS, the activity decreased to around a conversion rate of $43 \%$. Deposition of the impurities and coke on the surface of the catalysts is responsible for the deactivation of the catalysts. Reusability tests revealed that the catalyst displayed outstanding reusability and could be regenerated fully after several reusing rounds. Further investigation on catalyst design, reaction mechanism, and regeneration should facilitate the progress of bio-oil oxygenated compounds using silica-supported zinc catalysts. 
Author Contributions: Conceptualization, H.P., W.M.A.W.D. and F.A.; Methodology, H.P. and F.A.; Software, H.P. and M.K.A.; Validation, H.P., F.A. and W.M.A.W.D.; Formal analysis, H.P. and F.A.; investigation, H.P.; resources, F.A., W.M.A.W.D., M.K.A. and T.M.I.M.; Data curation, H.P. and F.A.; Writing-original draft preparation, H.P.; Writing-review and editing, F.A. and T.M.I.M.; Visualization, H.P.; Supervision, W.M.A.W.D., M.K.A. and F.A.; Project administration, W.M.A.W.D. and F.A.; Funding acquisition, W.M.A.W.D., F.A. and T.M.I.M. All authors have read and agreed to the published version of the manuscript.

Funding: The authors gratefully acknowledge the financial support from the University of Malaya, Malaysia, and the Deanship of Scientific Research (DSR) at King Abdulaziz University, Jeddah.

Acknowledgments: The authors gratefully acknowledge the financial support from the University of Malaya, Malaysia, and the Deanship of Scientific Research (DSR) at King Abdulaziz University, Jeddah.

Conflicts of Interest: The authors declare no conflict of interest.

\section{References}

1. Ismail, M.; Moghavvemi, M.; Mahlia, T.M.I. Characterization of PV panel and global optimization of its model parameters using genetic algorithm. Energy Convers. Manag. 2013, 73, 10-25. [CrossRef]

2. Alinejad, M.; Arof, A.K. Effect of Extraction Time and Concentration of Crocus sativus on Behavior of Dye-Sensitized Solar Cells. Ionics 2017, 23, 1579-1584. [CrossRef]

3. Mason, I.; Page, S.; Williamson, A. A 100\% renewable electricity generation system for New Zealand utilising hydro, wind, geothermal and biomass resources. Energy Policy 2010, 38, 3973-3984. [CrossRef]

4. Silitonga, A.; Shamsuddin, A.; Mahlia, T.M.I.; Milano, J.; Kusumo, F.; Siswantoro, J.; Dharma, S.; Sebayang, A.; Masjuki, H.; Ong, H.C. Biodiesel synthesis from Ceiba pentandra oil by microwave irradiation-assisted transesterification: ELM modeling and optimization. Renew. Energy 2020, 146, 1278-1291. [CrossRef]

5. Ong, H.C.; Milano, J.; Silitonga, A.S.; Hassan, M.H.; Shamsuddin, A.H.; Wang, C.-T.; Mahlia, T.M.I.; Siswantoro, J.; Kusumo, F.; Sutrisno, J. Biodiesel production from Calophyllum inophyllum-Ceiba pentandra oil mixture: Optimization and characterization. J. Clean. Prod. 2019, 219, 183-198. [CrossRef]

6. Mahlia, T.; Syazmi, Z.; Mofijur, M.; Abas, A.P.; Bilad, M.; Ong, H.C.; Silitonga, A. Patent landscape review on biodiesel production: Technology updates. Renew. Sustain. Energy Rev. 2020, 118, 109526. [CrossRef]

7. Ong, H.C.; Hassan, M.; Mahlia, T.M.I.; Silitonga, A.S.; Chong, W.T.; Yusaf, T. Engine performance and emissions using Jatropha curcas, Ceiba pentandra and Calophyllum inophyllum biodiesel in a CI diesel engine. Energy 2014, 69, 427-445. [CrossRef]

8. Silitonga, A.S.; Masjuki, H.; Mahlia, T.M.I.; Ong, H.; Chong, W.T.; Boosroh, M. Overview properties of biodiesel diesel blends from edible and non-edible feedstock. Renew. Sustain. Energy Rev. 2013, 22, 346-360. [CrossRef]

9. Bhatt, A.H.; Zhang, Y.M.; Heath, G.A. Air Pollutant Emissions and Regulatory Implications of Co-Processing Raw Bio-Oil in US Petroleum Refineries; National Renewable Energy Lab (NREL): Golden, CO, USA, 2020.

10. Pourzolfaghar, H.; Abnisa, F.; Daud, W.M.A.W.; Aroua, M.K. Atmospheric hydrodeoxygenation of bio-oil oxygenated model compounds: A review. J. Anal. Appl. Pyrolysis 2018, 133, 117-127. [CrossRef]

11. Lee, X.J.; Ong, H.; Gan, Y.Y.; Chen, W.-H.; Mahlia, T.M.I. State of art review on conventional and advanced pyrolysis of macroalgae and microalgae for biochar, bio-oil and bio-syngas production. Energy Convers. Manag. 2020, 210, 112707. [CrossRef]

12. Goh, B.H.H.; Ong, H.; Cheah, M.Y.; Chen, W.-H.; Yu, K.L.; Mahlia, T.M.I. Sustainability of direct biodiesel synthesis from microalgae biomass: A critical review. Renew. Sustain. Energy Rev. 2019, 107, 59-74. [CrossRef]

13. Kim, S.; Kwon, E.E.; Kim, Y.T.; Jung, S.; Kim, H.J.; Huber, G.W.; Lee, J. Recent advances in hydrodeoxygenation of biomass-derived oxygenates over heterogeneous catalysts. Green Chem. 2019, 21, 3715-3743. [CrossRef]

14. Boullosa-Eiras, S.; Lødeng, R.; Bergem, H.; Stocker, M.; Hannevold, L.; Blekkan, A. Catalytic hydrodeoxygenation (HDO) of phenol over supported molybdenum carbide, nitride, phosphide and oxide catalysts. Catal. Today 2014, 223, 44-53. [CrossRef]

15. Prasomsri, T.; Nimmanwudipong, T.; Román-Leshkov, Y. Effective hydrodeoxygenation of biomass-derived oxygenates into unsaturated hydrocarbons by MoO3 using low $\mathrm{H} 2$ pressures. Energy Environ. Sci. 2013, 6, 1732. [CrossRef]

16. Prasomsri, T.; Shetty, M.; Murugappan, K.; Román-Leshkov, Y. Insights into the catalytic activity and surface modification of MoO 3 during the hydrodeoxygenation of lignin-derived model compounds into aromatic hydrocarbons under low hydrogen pressures. Energy Environ. Sci. 2014, 7, 2660-2669. [CrossRef] 
17. Chen, C.-J.; Lee, W.-S.; Bhan, A. Mo2C catalyzed vapor phase hydrodeoxygenation of lignin-derived phenolic compound mixtures to aromatics under ambient pressure. Appl. Catal. A Gen. 2016, 510, 42-48. [CrossRef]

18. Nimmanwudipong, T.; Runnebaum, R.C.; Block, D.E.; Gates, B.C. Catalytic Conversion of Guaiacol Catalyzed by Platinum Supported on Alumina: Reaction Network Including Hydrodeoxygenation Reactions. Energy Fuels 2011, 25, 3417-3427. [CrossRef]

19. Zhu, X.; Lobban, L.L.; Mallinson, R.G.; Resasco, D.E. Bifunctional transalkylation and hydrodeoxygenation of anisole over a Pt/HBeta catalyst. J. Catal. 2011, 281, 21-29. [CrossRef]

20. Zanuttini, M.; Costa, B.D.; Querini, C.; Peralta, M. Hydrodeoxygenation of m-cresol with Pt supported over mild acid materials. Appl. Catal. A Gen. 2014, 482, 352-361. [CrossRef]

21. Olcese, R.N.; Francois, J.; Bettahar, M.M.; Petitjean, D.; Dufour, A. Hydrodeoxygenation of Guaiacol, A Surrogate of Lignin Pyrolysis Vapors, Over Iron Based Catalysts: Kinetics and Modeling of the Lignin to Aromatics Integrated Process. Energy Fuels 2013, 27, 975-984. [CrossRef]

22. Olcese, R.; Bettahar, M.; Malaman, B.; Ghanbaja, J.; Tibavizco, L.; Petitjean, D.; Dufour, A. Gas-phase hydrodeoxygenation of guaiacol over iron-based catalysts. Effect of gases composition, iron load and supports (silica and activated carbon). Appl. Catal. B Environ. 2013, 129, 528-538. [CrossRef]

23. Palla, V.C.S.; Shee, D.; Maity, S.K. Kinetics of hydrodeoxygenation of octanol over supported nickel catalysts: A mechanistic study. RSC Adv. 2014, 4, 41612-41621. [CrossRef]

24. Ausavasukhi, A.; Huang, Y.; To, A.T.; Sooknoi, T.; Resasco, D.E. Hydrodeoxygenation of m-cresol over gallium-modified beta zeolite catalysts. J. Catal. 2012, 290, 90-100. [CrossRef]

25. Wan, S.; Pham, T.; Zhang, S.; Lobban, L.; Resasco, D.; Mallinson, R.G. Direct catalytic upgrading of biomass pyrolysis vapors by a dual function $\mathrm{Ru} / \mathrm{TiO}_{2}$ catalyst. AIChE J. 2013, 59, 2275-2285. [CrossRef]

26. Ren, H.; Chen, Y.; Huang, Y.; Deng, W.; Vlachos, D.G.; Chen, J.G. Tungsten carbides as selective deoxygenation catalysts: Experimental and computational studies of converting C3 oxygenates to propene. Green Chem. 2014, 16, 761-769. [CrossRef]

27. Zhao, H.; Li, D.; Bui, P.; Oyama, S.T. Hydrodeoxygenation of guaiacol as model compound for pyrolysis oil on transition metal phosphide hydroprocessing catalysts. Appl. Catal. A Gen. 2011, 391, 305-310. [CrossRef]

28. Joshi, N.; Lawal, A. Hydrodeoxygenation of acetic acid in a microreactor. Chem. Eng. Sci. 2012, 84, 761-771. [CrossRef]

29. Yang, J.; Li, S.; Zhang, L.; Liu, X.; Wang, J.; Pan, X.; Li, N.; Wang, A.; Cong, Y.; Wang, X.; et al. Hydrodeoxygenation of furans over $\mathrm{Pd}-\mathrm{FeOx} / \mathrm{SiO} 2$ catalyst under atmospheric pressure. Appl. Catal. B Environ. 2017, 201, 266-277. [CrossRef]

30. Zhao, X.; Wei, L.; Cheng, S.; Cao, Y.; Julson, J.; Gua, Z. Catalytic cracking of carinata oil for hydrocarbon biofuel over fresh and regenerated Zn/Na-ZSM-5. Appl. Catal. A Gen. 2015, 507, 44-55. [CrossRef]

31. Viswanadham, N.; Pradhan, A.; Ray, N.; Vishnoi, S.; Shanker, U.; Rao, T.P. Reaction pathways for the aromatization of paraffins in the presence of H-ZSM-5 and Zn/H-ZSM-5. Appl. Catal. A Gen. 1996, 137, 225-233. [CrossRef]

32. Smiekova, A. Aromatization of light alkanes over ZSM- 5 catalystsInfluence of the particle properties of the zeolite. Appl. Catal. A Gen. 2004, 268, 235-240. [CrossRef]

33. Li, Y.; Liu, S.; Xie, S.; Xu, L. Promoted metal utilization capacity of alkali-treated zeolite: Preparation of Zn/ZSM-5 and its application in 1-hexene aromatization. Appl. Catal. A Gen. 2009, 360, 8-16. [CrossRef]

34. Fanchiang, W.-L.; Lin, Y.-C. Catalytic fast pyrolysis of furfural over H-ZSM-5 and Zn/H-ZSM-5 catalysts. Appl. Catal. A Gen. 2012, 419, 102-110. [CrossRef]

35. Luzgin, M.V.; Rogov, V.A.; Arzumanov, S.S.; Toktarev, A.V.; Stepanov, A.G.; Parmon, V.N. Methane aromatization on $\mathrm{Zn}$-modified zeolite in the presence of a co-reactant higher alkane: How does it occur? Catal. Today 2009, 144, 265-272. [CrossRef]

36. Ni, Y.; Sun, A.; Wu, X.; Hai, G.; Hu, J.; Li, T.; Li, G. The preparation of nano-sized H[Zn, Al]ZSM-5 zeolite and its application in the aromatization of methanol. Microporous Mesoporous Mater. 2011, 143, 435-442. [CrossRef]

37. Fang, Y.; Tang, J.; Huang, X.; Shen, W.; Song, Y.; Sun, C. Aromatization of Dimethyl Ether over Zn/H-ZSM-5 Catalyst. Chin. J. Catal. 2010, 31, 264-266. [CrossRef]

38. Hu, Y.; Song, T.-Y.; Wang, Y.-J.; Hu, G.; Xie, G.; Luo, M. Gas Phase Dehydrochlorination of 1, 1, 2-Trichloroethane over Zn/SiO2 Catalysts: Acidity and Deactivation. Acta Phys.-Chim. Sin. 2017, 33, 1-11. 
39. Klein, I.; Marcum, C.; Kenttamaa, H.I.; Abu-Omar, M.M. Mechanistic investigation of the Zn/Pd/C catalyzed cleavage and hydrodeoxygenation of lignin. Green Chem. 2016, 18, 2399-2405. [CrossRef]

40. Parsell, T.H.; Jarrell, T.M.; Haupert, L.J.; Amundson, L.M.; Abu-Omar, M.M.; Owen, B.J.; Klein, I.; Marcum, C.; Kenttamaa, H.I.; Ribeiro, F.H.; et al. Cleavage and hydrodeoxygenation (HDO) of C-O bonds relevant to lignin conversion using Pd/Zn synergistic catalysis. Chem. Sci. 2013, 4, 806-813. [CrossRef]

41. Mirzayanti, Y.W.; Prajitno, D.H.; Roesyadi, A. Catalytic hydrocracking of Kapuk seed oil (Ceiba pentandra) to produce biofuel using Zn-Mo supported HZSM-5 catalyst. IOP Conf. Ser. Earth Environ. Sci. 2017, 67, 12023. [CrossRef]

42. Pourzolfaghar, H.; Abnisa, F.; Daud, W.M.A.W.; Aroua, M.K. Gas-phase hydrodeoxygenation of phenol over $\mathrm{Zn} / \mathrm{SiO} 2$ catalysts: Effects of zinc load, temperature, weight hourly space velocity, and $\mathrm{H} 2$ volumetric flow rate. Biomass Bioenergy 2020, 138, 105556. [CrossRef]

43. Rusu, D.; Rusu, G.; Luca, D. Structural Characteristics and Optical Properties of Thermally Oxidized Zinc Films. Acta Phys. Pol. A 2011, 119, 850-856. [CrossRef]

44. Sacco, O.; Vaiano, V.; Sannino, D.; Picca, R.; Cioffi, N. Ag modified ZnS for photocatalytic water pollutants degradation: Influence of metal loading and preparation method. J. Colloid Interface Sci. 2019, 537, 671-681. [CrossRef]

45. Nie, L. Catalytic Hydrodeoxygenation of Phenolic Compounds of Importance in Bio-oil Upgrading. 2014. Available online: https://hdl.handle.net/11244/10369 (accessed on 21 March 2020).

46. Oyama, S.T.; Clark, P.; Da Silva, V.T.; Lede, E.J.; Requejo, F.G. XAFS Characterization of Highly Active Alumina-Supported Molybdenum Phosphide Catalysts (MoP/Al2O3) for Hydrotreating. J. Phys. Chem. B 2001, 105, 4961-4966. [CrossRef]

47. Phillips, D.C.; Sawhill, S.J.; Self, R.; Bussell, M.E. Synthesis, Characterization, and Hydrodesulfurization Properties of Silica-Supported Molybdenum Phosphide Catalysts. J. Catal. 2002, 207, 266-273. [CrossRef]

48. Clark, P.; A Clark, P.; Oyama, S.T. Alumina-supported molybdenum phosphide hydroprocessing catalysts. J. Catal. 2003, 218, 78-87. [CrossRef]

49. Asphaug, S. Catalytic Hydrodeoxygenation of Bio-oils with Supported MoP-Catalysts. Master's Thesis, Norwegian University of Science and Technology, Trondheim, Norway, 2013.

50. Karnjanakom, S.; Bayu, A.; Hao, X.; Kongparakul, S.; Samart, C.; Abudula, A.; Guan, G.-Q. Selectively catalytic upgrading of bio-oil to aromatic hydrocarbons over $\mathrm{Zn}, \mathrm{Ce}$ or Ni-doped mesoporous rod-like alumina catalysts. J. Mol. Catal. A Chem. 2016, 421, 235-244. [CrossRef]

51. Huynh, T.M.; Armbruster, U.; Kreyenschulte, C.R.; Nguyen, L.H.; Phan, B.M.Q.; Nguyen, D.A.; Martin, A. Understanding the Performance and Stability of Supported Ni-Co-Based Catalysts in Phenol HDO. Catalysts 2016, 6, 176. [CrossRef]

52. Bu, Q.; Lei, H.; Zacher, A.H.; Wang, L.; Ren, S.; Liang, J.; Wei, Y.; Liu, Y.; Tang, J.; Zhang, Q.; et al. A review of catalytic hydrodeoxygenation of lignin-derived phenols from biomass pyrolysis. Bioresour. Technol. 2012, 124, 470-477. [CrossRef]

53. Echeandia, S.; Arias, P.L.; Barrio, V.; Pawelec, B.; Fierro, J.L.G. Synergy effect in the HDO of phenol over $\mathrm{Ni}-\mathrm{W}$ catalysts supported on active carbon: Effect of tungsten precursors. Appl. Catal. B Environ. 2010, 101, 1-12. [CrossRef]

54. Zhao, C.; He, J.; Lemonidou, A.A.; Li, X.; Lercher, J.A. Aqueous-phase hydrodeoxygenation of bio-derived phenols to cycloalkanes. J. Catal. 2011, 280, 8-16. [CrossRef]

(C) 2020 by the authors. Licensee MDPI, Basel, Switzerland. This article is an open access article distributed under the terms and conditions of the Creative Commons Attribution (CC BY) license (http://creativecommons.org/licenses/by/4.0/). 